УДК 947.084:39

ББК 63.3 (2Ки)

\title{
Опыт реконструкции политической биографии Сулеймана Кучукова
}

T.M. Аюnов

Алтайский государственный медицинский университет (Барнаул, Россия)

\section{Experience in Reconstructing the Political Biography of Suleiman Kuchukov}

T.M. Ayupov

Altai State Medical University (Barnaul, Russia)

\begin{abstract}
Статья посвящена легендарной личности Сулейману Кучукову - первому кадровому офицеру из числа киргизов, герою Первой мировой войны, одному из первых коннозаводчиков Киргизии и Узбекистана. Опираясь на опубликованные источники, документы архивных фондов и полевые исследования, автором предпринята попытка прояснить некоторые «белые пятна» в его биографии: предлагается правильное написание его имени, точные даты жизни и смерти, сведения о награждениях и т.д. Часть использованных материалов впервые вводится в научный оборот. Таким образом, развеиваются некоторые мифы, связанные с ним. Прослеживается боевой путь одного из первых национальных воинских соединений Кара-киргизского кавалерийского полка, которым в годы Гражданской войны командовал С. Кучуков. Кроме военной службы и хозяйственной деятельности, затрагивается также его личная жизнь и судьба потомков, среди которых две заслуженные артистки Узбекской ССР. Особое внимание уделяется вопросу национальной принадлежности командира. К сожалению, остаются не установленными истинные причины и обстоятельства внезапной гибели героя.
\end{abstract}

Ключевые слова: Сулейман Кучуков, Гражданская война, легенды, архивные документы, басмачи, коневодство, этническая идентификация.

DOI 10.14258/izvasu(2019)6-02

Сразу после установления советской власти в Туркестане, как и во многих регионах страны, начали создаваться отряды Красной Армии. Казахи, киргизы, узбеки, претерпевавшие много лишений от колониальной политики Российской империи, охотно вступали в создаваемые большевиками отряды добро-
The article is dedicated to the legendary person Suleiman Kuchukov, the first Kyrgyz cadre officer, a hero of the First World War, one of the first horse breeders in Kyrgyzstan and Uzbekistan. Based on published sources, documents from archival funds and field research, an attempt was made to clarify some of the "white spots" in his biography: the correct spelling of his name, exact dates of life and death, information about awards, etc. were proposed. Some of the materials used are introduced into scientific circulation for the first time. Thus, the article dispels some of the myths associated with him. The military route of one of the first national military formations, the Kara-Kyrgyz cavalry regiment, which Suleiman Kuchukov commanded during the Civil War, was traced. In addition to military service and economic activity, the personal life and fate of his descendants are also affected among which two honored artists of the Uzbek SSR. The author separately addresses the issue of the nationality of the commander, pointing to signs of ethnic marginalization of the individual. Unfortunately, the true causes and circumstances of the sudden death of the hero remain unclear.

Key words: Suleiman Kuchukov, Civil War, legends, archival documents, basmachi, horse breeding, ethnic identification. вольцев. Командирами этих частей в основном становились представители местных национальностей. Отличившиеся своим геройством и храбростью были удостоены высоких воинских наград.

В целом, советской исторической наукой был накоплен огромный эмпирический материал, 
посвященный событиям Октябрьской революции 1917 г. и Гражданской войны в Средней Азии. В 50-60-е гг. XX в. были опубликованы многочисленные мемуары участников борьбы с басмачеством. Печатались они в основном в местных издательствах и порой были практически единственным источником информации об отдельных эпизодах той войны, о жизни легендарных командиров Красной Армии и их противников - курбаши басмаческих отрядов. По этой причине достоверных сведений о биографии многих главных участников «классовой борьбы» в регионе мало, зато слишком много мифических.

Среди таких имен - Сулейман Юнусович Кучуков - первый кадровый офицер, вышедший из киргизского народа, которому довелось побывать по обе линии фронта. На фоне переосмысления событий Октября 1917 г. в последнее время интерес к нему как незаурядной исторической личности заметно вырос, что нашло свое отражение в ряде публикаций на русском и киргизском языках [1-4].

В литературе и архивных источниках даже даются разные варианты написания его фамилии (Кучуков, Кучаков, Кичиков), имени (Сулейман, Сулайман) и отчества (Юнусович, Жунусович, Юсупович, Юсуфович). Однако принимая во внимание факт написания его полного имени в Общем списке офицеров на 1909 г. и Картотеке Бюро по учету потерь на фронтах Первой мировой войны 1914-1918 гг., хранящихся в Российском государственном военно-историческом архиве [5], мы считаем первую форму написания наиболее верной.

Процесс изучения архивных материалов по теме исследования усложняется тем, что в минувших событиях подчас трудно выяснить подлинную этническую принадлежность действующих лиц: были они киргизами или казахами (последних в официальных документах русские именовали «киргиз-кайсаками»), узбеками или таджиками - по отношению ко всему оседлому населению оазисов употребляли название «сарт»; татарами или башкирами - коренные жители Средней Азии часто объединяли их в условный этнотермин «ногай».

Определение этнической принадлежности С. Кучукова, если подойти к этому с точки зрения формальной логики, основываясь на объективных фактах его официальной биографии, не составляет труда. По национальности он киргиз, по месту рождения - «туземец-мусульманин», «туркестанец». Но кто же тогда он по воспитанию, образованию и базовым культурным стереотипам? По типичной для его поколения идеологической обусловленности, общей для всех судьбе и характеру поведения, которыми, согласно формационной теории, и определяется этническая принадлежность - представитель новой исторической общности «советский народ»? Безусловно, подобные вопросы не могут быть второстепенными, они играют порой заметную роль в трактовке различных событий из биографии исторической личности.

Для разрешения этой проблемы мы привлекли ряд документов и материалов, выявленных в частных архивах бывшего научного сотрудника Института истории Академии наук Киргизской ССР А.И. Кунина и бывшего руководителя кружка «красных следопытов» Ошского Дома пионеров А.В. Барышева. Эти частные архивы, переданные нам вдовами их владельцев, содержат ценные материалы по периоду Гражданской и Великой Отечественной войн, собранные из фондов Военно-медицинского музея Минобороны СССР, государственных архивов Андижанской, Наманганской, Ферганской областей Узбекской ССР и Ленинабадской области Таджикской ССР. Для введения в научный оборот они были систематизированы и сданы в Ошский областной государственный архив политической документации. В данной статье некоторые из них нами обнародуются впервые. Это позволит взглянуть на проблему этнической принадлежности С. Кучукова не только с его собственной позиции, т.е. с точки зрения этнического самоопределения, но и с точки зрения этнической идентификации со стороны его окружения, других людей. Из-за возникающей в этой связи разницы акт этнического самоопределения иногда имеет трагический характер.

Судьба Сулеймана Юнусовича (в некоторых советских источниках - Юсуповича [6]) Кучукова весьма необычна. Родился он в 1889 г. в АлайГульчинской волости Ошского уезда Ферганской области и происходил из киргизского племени кипчак. В 1909 г. после окончания Оренбургского Неплюевского кадетского корпуса был произведен в подпоручики. Юноша, вероятно, был чрезвычайно горд и рад этому событию. Ни один его сверстник из Кичик-Алая и помышлять не мог об этом, так как царское правительство запрещало киргизам нести воинскую повинность, боясь выступления их против существовавшего режима под воздействием жизненных тягот и бесправного положения, в котором они находились. Это стало возможно только благодаря тому, что по документам Сулейман Кучуков проходил как башкир. Относительно смены его национальности есть несколько версий. По одной из них, в десять лет, приехав с отцом на ташкентский базар, он потерялся. Подобрал его богатый купец-башкир, промышлявший лошадьми. Бездетный, тот усыновил смышленого мальчишку, а когда пришло время, то устроил его в кадетский корпус. Впервые такую жизненную историю приводят Г. Жильцов и Н. Кузьмичев на страницах исто- 
рического романа «Война без фронта», основанного на подлинных событиях [7, с. 78-79]. Многие ее герои - реально существовавшие люди. Этой же версии придерживался кандидат исторических наук А.И. Кунин [8, с. 49-50].

Следовательно, мы можем предполагать, что приемного отца мальчика звали Юнус Кучуков (по-башк. Юныс Көсөков) и умер он в 1911 г. В прошлом среди имен-оберегов у башкир были распространены имена с основой «көсөк» (щенок собаки, кутенок): Аккөсөк, Көсөккол, Көсөкбай, Эткөсөк. Такие имена давали новорожденным при частой смерти в семье детей в раннем возрасте. Этот обряд нашел отражение и в башкирском фольклоре. В частности, в одном предании говорится, что у некоего предводителя рода не выживали дети. Каждый год рождались и всякий раз умирали. Однажды у него родился черноволосый сын, чтобы его не тронула нечистая сила, бей назвал его Карагөсөк - Черный щенок [9, с. 68]. Многие исследователи полагают, что природа личных имен с компонентами «эт» (собака), «бүре» (волк), «айьу» (медведь) связана с тотемическими воззрениями древних башкир. В связи с принятием ислама также широкое распространение у башкир получили мусульманские имена пророков Мухаммад, Ибрагим, Юнус, Сулейман и др.

Видимо, по этой причине известный башкирский ученый и политический деятель АхметЗаки Валидов (Тоган) в своих мемуарах указывает на башкирское происхождение Кучукова. Они познакомились в 1913/1914 г. в Ташкенте в ходе научной поездки Валидова в Туркестан. В своем труде «Воспоминания», вышедшем в 1969 г. в Стамбуле, Валидов пишет об этом так: «За время поездки в Ташкент, Фергану, Самарканд и Бухару я приобрел немало новых друзей... Один из них, офицер русской армии, полковник, башкир по происхождению Абубакир Диваев, опубликовал немало ценных работ, посвященных этнографии казахского и киргизского народов. Он познакомил меня также с офицером башкиром Кусюковым...» [10, с. 131]. Фамилия Кучуков здесь приводится несколько по-иному, так как общетюркскому звуку [ч] в башкирском языке соответствует звук [c].

Согласно второй версии Сулейман Кучуков записался башкиром по иной причине. В соответствии с Уставом о воинской повинности 1874 г. народности Средней Азии, Казахстана, Северного Кавказа и Сибири в армию не призывались. Царское правительство боялось доверять им оружие. Поэтому, когда пришла «разнарядка» на зачисление в военное училище, знакомый Кучукова чиновник подделал его документы, поэтому он был призван в армию как башкир. Эта версия была впервые озвучена в 1971 г. участником установле- ния советской власти в Туркестане Д.В. Кордубом, проживавшим в Ташкенте. Данный отрывок из воспоминаний ветерана позднее был опубликован в книге отца и сына Музиповых «Партизаны» $[11$, c. 280].

Вторая версия нам кажется менее правдоподобной. Но, как бы то ни было, в период своей работы в Оше Сулейман Кучуков жил на улице Татарской $[12$, л. 8] (среди местных жителей известной как Ногай-махалля), где вплоть до середины 1950-х гг. селились преимущественно татары и башкиры. Такой микротопоним указан на схематическом плане Оша на 1919 г., разработанном по памяти старожила города Д.Д. Чуракова в 1958 г. Улица располагалась на левобережье реки Ак-Буры в новой — «европейской» - части города [13, с. 82-83]. Позднее она сдвинулась немного западнее и была расширена, получив новое название - Карла Маркса. Решением XXIV сессии Кенеша (орган городского самоуправления) в 2003 г. улицу переименовали в улицу Сагынбека Супаналиева.

Кроме того, в архивных фондах нам также встретился документ, где С. Кучуков значится как «казах» $[12$, л. 5]. Этот факт косвенно может указывать на то, что, несмотря на свою типично азиатскую внешность, по-видимому, из-за особенностей воспитания, он все же заметно отличался от коренного населения края.

Сведений о воинской службе Сулеймана Кучукова вплоть до Первой мировой войны не имеется. На фронте он командовал конной разведкой 1-го Туркестанского стрелкового полка. Высочайшим приказом от 25 апреля 1915 г. он был награжден орденом Святого Георгия 4-й степени [5]. Очевидно, что молодого офицера манила романтика армейской службы: в годы войны он проявил незаурядное мужество.

По этому поводу существуют несколько красивых легенд. Одна из них гласит, что как-то, будучи в чине штабс-капитана, он приехал в расположение одной из воинских частей недалеко от Пинска, где стал свидетелем необычной картины. Противник укрепил на проволочных заграждениях нейтральной полосы в хорошо простреливаемой местности труп генерала Гуревича - известного кутилы и родственника дома Романовых. Одержимый желанием выиграть пари, он повел полк в неподготовленную атаку, уверяя, что прорвет оборону немцев. Пустая затея стоила многих солдатских жизней и самого инициатора наступления. Выполняя приказ доставить тело Гуревича в расположение полка, десятки смельчаков сложили головы у проволочных заграждений. С. Кучуков сам решил снять злополучный труп. И это ему удалось, за что английский посол от имени своего короля прикрепил к мундиру героя орден «За особую 
храбрость» [7, с. 79]. В источниках можно найти также сведения о том, что Кучуков был полным георгиевским кавалером и кавалером ордена Святой Анны. Эта легенда не соответствует действительности, поскольку идет вразрез со статутом данных наград, а имя Кучукова не найдено в соответствующих наградных списках.

После 1917 г. судьба Сулеймана Кучукова ничем не отличалась от судеб тысяч русских офицеров, оказавшихся на переломе эпох. Он прошел через полосу метаний и разочарований. Вернувшись с ЮгоЗападного фронта, в ноябре 1917 г. принял участие в антисоветском мятеже атамана А.И. Дутова и захвате Оренбурга, а после разгрома в марте 1918 г. основных сил мятежников через казахские степи вернулся в родные края.

Оказавшись в Оше, Кучуков с усердием взялся за новое ответственное дело - организацию государственного коневодческого хозяйства. Для скорейшей реализации планов в город были переведены Куршабские госконюшни и Кашгар-Кишлакский конезавод. Однако не все поддержали старания Сулеймана Кучукова, отдельные местные чиновники с опаской отнеслись к бывшему царскому офицеру. Этим поспешили воспользоваться контрреволюционные круги, стараясь вовлечь в свои ряды способного «военспеца». Ими был распространен провокационный слух о якобы готовящемся аресте Кучукова.

Для борьбы с басмачами в ноябре-декабре 1918 г. из русских и украинских крестьян Андижанского и Ошского уездов была создана так называемая Крестьянская армия. Позже проникшие в ее штаб бывший царский генерал А. Муханов и эсер К. Монстров своей агитацией добились того, что летом 1919 г. армия, объединившись с отрядами курбаши Мадаминбека, выступила против советской власти. В этой армии Сулейман Кучуков, уже в чине полковника, очевидно, присвоенного ему ставкой «Верховного правителя России», был назначен командиром сводного батальона, куда входили «крестьяне» Монстрова, басмачи курбаши Мойдунбека и офицеры Памирского погранотряда, перешедшие на сторону мятежников $[14$, с. 50]. Всего батальон насчитывал 1500 штыков. Войдя в состав Военного совета объединенной мятежной армии, С. Кучуков лично руководил штурмом городов Ош и Джалал-Абад в сентябре 1919 г. В частности, именно ему принадлежал план затопить Ошскую крепость, направив сюда течение поливных каналов (арыков). Вскоре Кучуков возглавил сформированный по предложению Монстрова отдельный Кара-киргизский кавалерийский полк. Для этого он специально ездил в с. Гульчу, где по окрестным аилам набрал около 200 метких охотников, а потом занимался их кавалерийским обучением.
Однако в его поведении с самого начала все же наблюдалась некая растерянность. Так, например, 10 сентября в бою под с. Араван он дал возможность отряду командующего Ферганским фронтом Сафонова выйти из ущелья и таким образом избежать окружения. Затем, наступая на Андижан с югозападного направления, не развивал активных действий $[15$, с. 79$]$. Еще была неудачная поездка в Индию поздней осенью 1919 г. Сулейман Кучуков был послан с письмом к тамошнему политическому агенту, минуя английского консула в Кашгаре Эссертона. Однако люди последнего догнали Кучукова у самой цели и вернули назад под конвоем [7, с. 210].

Чувствуя неизбежность поражения, в феврале 1920 г. С. Кучуков порывает с недавними союзниками. Неожиданно для Монстрова он двинул свой полк на с. Гульчу и выбил оттуда последние остатки Крестьянской армии, а затем явился с повинной в штаб Ферганского фронта и заявил о своем окончательном переходе на сторону советской власти $[16$, с. 49-50].

В дальнейшем Кара-киргизский полк (в январе-июне 1920 г. - кавалерийский дивизион) отличился в наступлении на басмачей, закрепившихся на Памиро-Алае, а также принимал активное участие в ликвидации Бухарского эмирата. За разоружение Старо-Маргеланского полка, внушавшего сомнение в его лояльности к Советам, командир полка был отмечен именными золотыми часами. Надпись на них гласила: «Честному воину РККА от РВС Туркфронта» $[17$, c. 53-54].

Высоко оценивая героизм всех бойцов, М.В. Фрунзе издал приказ по Туркестанскому фронту, в котором отмечалось: «В половине минувшего мая обстановка потребовала направления в Алайскую долину особого отряда для разгрома сосредоточившихся там басмаческих шаек. Несмотря на то, что поход пришлось совершать по высокому Алайскому хребту, неоднократно проходить по крутым, каменистым перевалам при тяжелых климатических условиях, пробивая себе дорогу боем, отряд блестяще выполнил свою задачу, разметал всю басмаческую организацию и гнал ее остатки до бухарского города Гарма. Особой лихостью и энергией отличился Кара-киргизский дивизион, показавший себя отлично сплоченной, дисциплинированной и вполне надежной частью. Считаю для себя приятным долгом отметить столь беззаветно доблестную службу конного отряда и объявляю всему командному составу и товарищам красноармейцам самую сердечную благодарность...» [6, с. 205-206]. Приказ был объявлен во всех ротах, эскадронах, батареях и командах красноармейских частей Туркестанского фронта.

17 октября 1923 г. приказом Реввоенсовета СССР Кучуков был удостоен высшей революционной награды - ордена Красного Знамени. На Ферганском 
фронте даже ходил рассказ, что после Алайского похода, в котором отличился Кара-киргизский дивизион, М.В. Фрунзе лично снял со своей груди орден Красного Знамени и прикрепил его на грудь Кучукова [18, с. 59].

В бою с отрядами «ляшкарбаши» Курширмата у кишлака Кара-Сакал Кучуков был тяжело ранен. Рана оказалась серьезной: пуля порвала сухожилия под коленом. После госпиталя его комиссовали, и он вернулся в Ош на «дипломатическую» работу: уговаривал мелких курбашей сложить оружие. Позже Сулейман Юнусович (вступив в ряды большевиков) заведовал Джалал-Абадскими конюшнями, подготавливал конные резервы для воинских частей, активно способствуя окончательному разгрому басмачества в Южной Киргизии [12, л. 8]. Коневодство было еще одной его страстью: как и всякий киргиз, он был прирожденным наездником. Возможно и то, что особую любовь к лошадям ему мог привить приемный отец, знавший в них толк. Опять же по легенде, С. Кучуков был инициатором создания ташкентского ипподрома [19].

В 1932 г. в возрасте 43 лет прославленного командира не стало. По расплывчатым формулировкам советских источников он «трагически погиб от рук классового врага». Однако его дочь впоследствии свидетельствовала о том, что отца сначала вызвали в Москву, якобы на повышение, а потом его тело было найдено «растерзанным на железнодорожных путях» [19].

Учитывая, что детям Сулеймана Кучукова пришлось сменить фамилию на Кучликовых, можно представить всю трудность положения, в котором оказалась его вдова - учительница начальных классов Хасият Миркаримова. Лишь благодаря помощи ее родственника Рустама Исламова, работавшего в Наркомате земледелия Узбекской ССР, от государства семье была назначена персональная пенсия.

Всего в семье Кучуковых родилось 13 детей, но выжили только восемь. Двое из них - оперные певицы Ойниса и Рафаат Кучликовы - в течение полувека блистали на сцене Государственного академического Большого театра им. А. Навои. Рафаат Сулеймановна особо запомнилась своим исполнением пар- тий Чио-Чио-Сан в опере «Мадам Баттерфляй», Микаэль в «Кармен», Татьяны в «Евгении Онегине», Маргариты в «Фаусте», Джамили в опере «Лейли и Меджнун». Ойниса Сулеймановна, также пользовавшаяся неизменным успехом у слушателя, долгие годы обеспечивала домашний уют и покой своему супругу - известному узбекскому композитору А. Абдукаюмову. Ойниса и Рафаат Кучликовы стали заслуженными артистками Узбекистана. Многие в Ташкенте воспринимали сестер уже как представительниц узбекского народа, хотя и отмечали в их языке специфический говор [20].

Своего знаменитого отца сестры Ойниса и Рафаат практически не запомнили, знали только из рассказов близких людей и скупых документальных сведений. «Папа был от природы умным и способным к языкам, - делилась воспоминаниями об отце Рафаат Кучликова - он прекрасно играл на рояле, на дутаре, как и на других узбекских инструментах, многие из которых долгое время хранились у нас дома» [19].

И это, безусловно, заслуга его приемного отца. Сердобольный башкирский купец не только взял мальчика к себе и усыновил, но и дал ему хорошее образование, привил европейскую культуру. Именно в стенах Оренбургского Неплюевского кадетского корпуса будущий герой постигал азы военного искусства, формировался как офицер и настоящий патриот.

Принадлежность к двум этносам многие считают преимуществом, выражающимся в более широких взглядах на окружающий мир. Тесные межэтнические контакты дают массу положительного личности и обществу, прежде всего высокий уровень толерантности к традициям, языку, религии и обличию других народов.

Героическими делами был отмечен боевой путь Кара-киргизского полка - одного из первых национальных воинских формирований. 95\% его состава составляли киргизы, прошедшие суровую школу Гражданской войны. Для многих из них Сулейман Кучуков, славный сын двух родственных народов, был первым наставником и боевым командиром.

\section{Библиографический список}

1. Муратов А. Оош-кыйыш замандагы оош-кыйыш тагдыр, же Сулайман Күчүков тууралуу эмнелерди билебиз? // ZAMAN Кыргызстан. 2012-жыл, 28-сентябрь, 5-октябрь (на кирг. яз.).

2. Сумароков Л.И. Кавалер Святого Георгия // Одна судьба - одна дорога. Бишкек, 2014.
3. Абытов Б.К. Сулайман Кучуков - герой первой мировой и гражданской войны // Известия ОшТУ. 2016. №2.

4. Федорчук А. Сулейман Кучуков: кавалер, басмач, краском. URL: https://www.alv.me/sulejman-kuchukovkavaler-basmach-kras/ (дата обращения: 29.01.2017). 
5. Кавалеры ордена Святого Георгия IV класса. URL: https://ru.wikipedia.org/wiki/ (дата обращения: 29.01.2017).

6. История Киргизской ССР: с древнейших времен до наших дней : в 5 т. Т. 3. Фрунзе, 1986.

7. Жильцов Г., Кузьмичев Н. Война без фронта : роман. Фрунзе, 1978.

8. Кунин А.И. Под алым стягом Октября. Фрунзе, 1985.

9. Фатыхова Ф.Ф. Наречение имени у башкир // Исследования по исторической этнографии Башкирии. Уфа, 1984.

10. Туған Вәлиди Әхмәтзәки. Хәтирәләр. Өфө, 1996 (на башк. яз.).

11. Музипов Г., Музипов Р. Партизаны : исторический роман. Углич, 2007.

12. Ошский областной государственный архив политической документации. Ф. 504. Оп. 1. Д. 1.
13. Захарова А. Историко-архитектурное наследие города Ош (конец XIX - начало XX вв.). Ош ; Дубай, 1997.

14. Ибодинов А. Қурбоши Мадаминбек (хужжатли қисса). Тошкент, 1993 (на узб. яз.).

15. Малышев К. Борьба за Советы в Киргизии и Туркестане. Фрунзе, 1958.

16. Айдашев Т. Город Ош: краткий краеведческий очерк. Фрунзе, 1968.

17. Кунин А.И. М.В. Фрунзе в борьбе за Советский Туркестан. Фрунзе, 1989.

18. Волков К., Полыковский М. Фаэтон со звездой : повесть. Ташкент, 1968.

19. Павленко А. Рафаат Кучликова: Чио-Чио-сан моя жизнь. URL: https:/www.proza.ru/2009/12/19/629 (дата обращения: 29.01.2017).

20. Полевые записи автора. Тетрадь №8 (начата в 2016 г.). 